\title{
ICE-FLOW AND THICKNESS MEASUREMENTS IN THE SØR-RONDANE, DRONNING MAUD LAND, ANTARGTICA
}

\author{
By T. Van Autenboer* and K. V. Blaiklock* \\ (Centre National de Recherches Polaires de Belgique, c/o Institut Géologique de l’Université, \\ Louvain, Belgium)
}

\begin{abstract}
Velocity and ice-thickness profiles were measured on the western glaciers of the Sør-Rondane during the Expéditions Antarctiques Belges of 1959 and 1960 . Some of the stations were re-occupied for velocity measurements during the Expédition Antarctique Belgo-Néerlandaise, Campagne d'Été r $964-65$.

The profiles, with stations at $\mathrm{I}$ mile $(\mathrm{I} .6 \mathrm{~km}$.) intervals, were generally east-west and at right-angles to the direction of flow of the plateau outlet glaciers. The movement was measured by resection of each station from the main triangulation points over periods ranging from 256 to 1,501 days. Double ties with a Worden geodetictype gravity meter were measured between the stations. An additional gravity station was occupied on rock at each end of the profile. The ice thickness and the subglacial topography are calculated from the gravity profiles. Combined with the surface velocity, they allow an estimate of the discharge of the glacier. The results indicate a close relationship between the glacier flow and the supply from the Antarctic Ice Sheet, as demonstrated by a study of the aerial photographs.
\end{abstract}

Résumé. Mesures d'écoulement de glace et d'ébaisseur dans le Sor-Rondane, Dronning Maud Land, Antarctique. Des profils de vitesse et d'épaisseur de glace ont été mesurés sur les glaciers ouest du Sør-Rondane pendant les Expéditions Antarctiques Belges de 1959 et 1960 . Quelques unes des stations ont été réoccupées pour des mesures de vitesse pendant la campagne d'été de l'Expédition Antarctique Belgo-Néerlandaise I964-65.

Les profils, avec un intervalle de $1,6 \mathrm{~km}$ entre les stations, étaient dirigés en général est-ouest et perpendiculairement à la direction d'écoulement des glaciers effluents du plateau. Le mouvement de chaque station était déterminé par relèvement des points principaux de la triangulation avec une période entre 256 et I 501 jours. Des rattachements doubles avec un gravimètre géodésique Worden ont été effectués entre les stations. Une station gravimétrique supplémentaire fut établie à chaque extrémité du profil sur la roche. L'épaisseur de la glace et la topographie sous-glaciaire ont été calculées à partir des profils gravimétriques. Combinés avec la vitesse superficielle, ils permettent une estimation du débit des glaciers. Les résultats indiquent une relation étroite entre l'écoulement glaciaire et l'apport de l'Indlandsis Antarctique déjà démontré par l'étude des photographies aériennes.

Zusammenfassung. Geschwindigkeits- und Eisdickenmessungen in Sar-Rondane, Dronning Maud Land, Antarktika. Auf den westlichen Gletschern von Sør-Rondane wurden während der Belgischen Antarktis-Expeditionen von 1959 und 1960 Geschwindigkeits- und Eisdickenprofile gemessen. Einige Stationen wurden für Geschwindigkeitsmessungen während der Sommerkampagne der Belgisch-Niederländischen Antarktis-Expedition I $964 / 65$ wiederbesetzt.

Die Profile, deren Stationen in Abständen von I Meile $(\mathrm{I}, 6 \mathrm{~km})$ lagen, waren im allgemeinen ost-west gerichtet und senkrecht zur Fliessrichtung der Ausflussgletscher des Polplateaus. Die Bewegung wurde durch Rückwärtseinschneiden jeder Station nach den Hauptdreieckspunkten über Perioden zwischen 256 und I 50 I Tagen gemessen. Mit einem Worden-Gravimeter geodätischer Bauart wurden Doppellinien zwischen den Stationen beobachtet. An jedem Profilende wurden im Felsgelände zusätzliche Gravimeterstationen besetzt. Aus den Schwerkraftprofilen wurde die Eisdicke und die subglaziale Topographie hergeleitet. In Verbindung mit der Oberflächengeschwindigkeit lassen sie eine Abschätzung des Gletscherausstosses zu. Die Ergebnisse deuten auf eine enge Beziehung zwischen dem Gletscherfluss und dem Nachschub aus dem antarktischen Inlandeis, wie sich anhand von Luftbildern zeigen lässt.

\section{INTRODUCTION}

The 1959 and 1960 Expéditions Antarctiques Belges were organized by the Centre National de Recherches Polaires de Belgique. The expeditions' headquarters, “Base Roi Baudouin" (lat. $70^{\circ} 26^{\prime} \mathrm{S}$., long. $24^{\circ}$ I $9^{\prime}$ E.), were constructed by the $195^{8}$ Expédition Antarctique Belge. The programme of the expeditions included geological, gravity and geodetic surveys by the authors. The bulk of these investigations deal with the Sør-Rondane, an impressive mountain range approximately $200 \mathrm{~km}$. south of "Base Roi Baudoin" (Fig. I). In addition to their main programme, the authors undertook movement and ice-thickness measurements on some of the glaciers in the western part of this range. The main results of these measurements are reviewed in this paper. The Campagne d'Été, Expédition Antarctique Belgo-Néerlandaise, r 964-65, was organized by the Comité Antarctique Belgo-Néerlandais.

* Fxpéditions Antarctiques Belges, 1959 and 1960, and Campagne d'Été Expédition Antarctique BelgoNéerlandaise, I $_{964}-65$. 


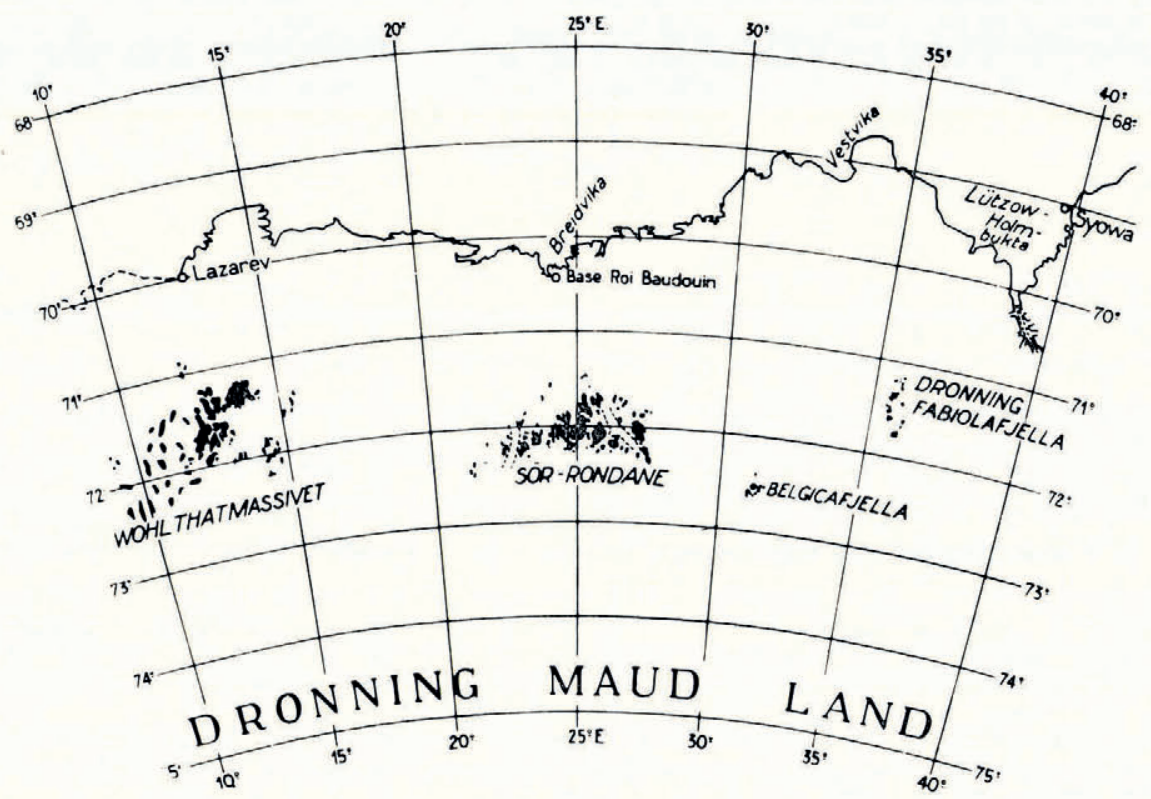

Fig. I. Eastern Dronning Maud Land. Belgicafjella were first photographed by the Expédition Antarctique Belge, 1958 (leader G. de Gerlache) and Dronning Fabiolafjella by the Expédition Antarctique Belge, 196o (leader G. Derom)

\section{The Sor-Rondane}

The Sør-Rondane forms a $250 \mathrm{~km}$. long, east-west, wedge-shaped mountain range which acts as a barrier and dams the glacier flow from the Antarctic Ice Sheet (Fig. 2). It seems that the flow in the unobstructed areas to the east and west of the mountain range is far more important than the flow through it. However, about i 5 major glaciers drain the ice from the polar plateau and subdivide the range into its main units. In general, these glaciers are orientated south to north but their direction may vary from north-north-west to north-east. Their widths range from 3 to $35 \mathrm{~km}$. and their lengths increase eastwards, reaching a maximum of $80 \mathrm{~km}$. (Byrdbreen).

In addition to the main drainage glaciers, the Sør-Rondane has its own well-developed glacierization system which is dependent entirely upon local conditions. Alpine, cirque and niche glaciers, and small ice caps occur within the range.

North of the range the confluence of the Sør-Rondane glaciers forms a piedmont zone (inland ice slope) but, as individual geographic features, the glaciers have disappeared. Near "Base Roi Baudouin" the inland ice slope joins the ice shelf.

The Sør-Rondane offers a wealth of evidence to establish the diminution of glacierization. Dry glacial valleys, extensive mammillated surfaces and vast moraine-covered areas are abundant throughout the range. There is considerable reduction in glacierization both on the polar plateau (and its drainage northwards) and locally.

A general account of the range has been given by Van Autenboer (1962), and more detailed data on glacierization and deglaciation are given by Van Autenboer ( 1964 [a]).

A map on a scale of 1 : 250,000, drawn from air photographs taken by the U.S. Navy Antarctic expedition of 1946-47 (Operation "Highjump") and published by the Norsk Polarinstitutt in 1957, proved to be most valuable during the field work. However, the altitudes have had to be changed materially as a result of the triangulation and barometric profiles by Blaiklock (unpublished). 


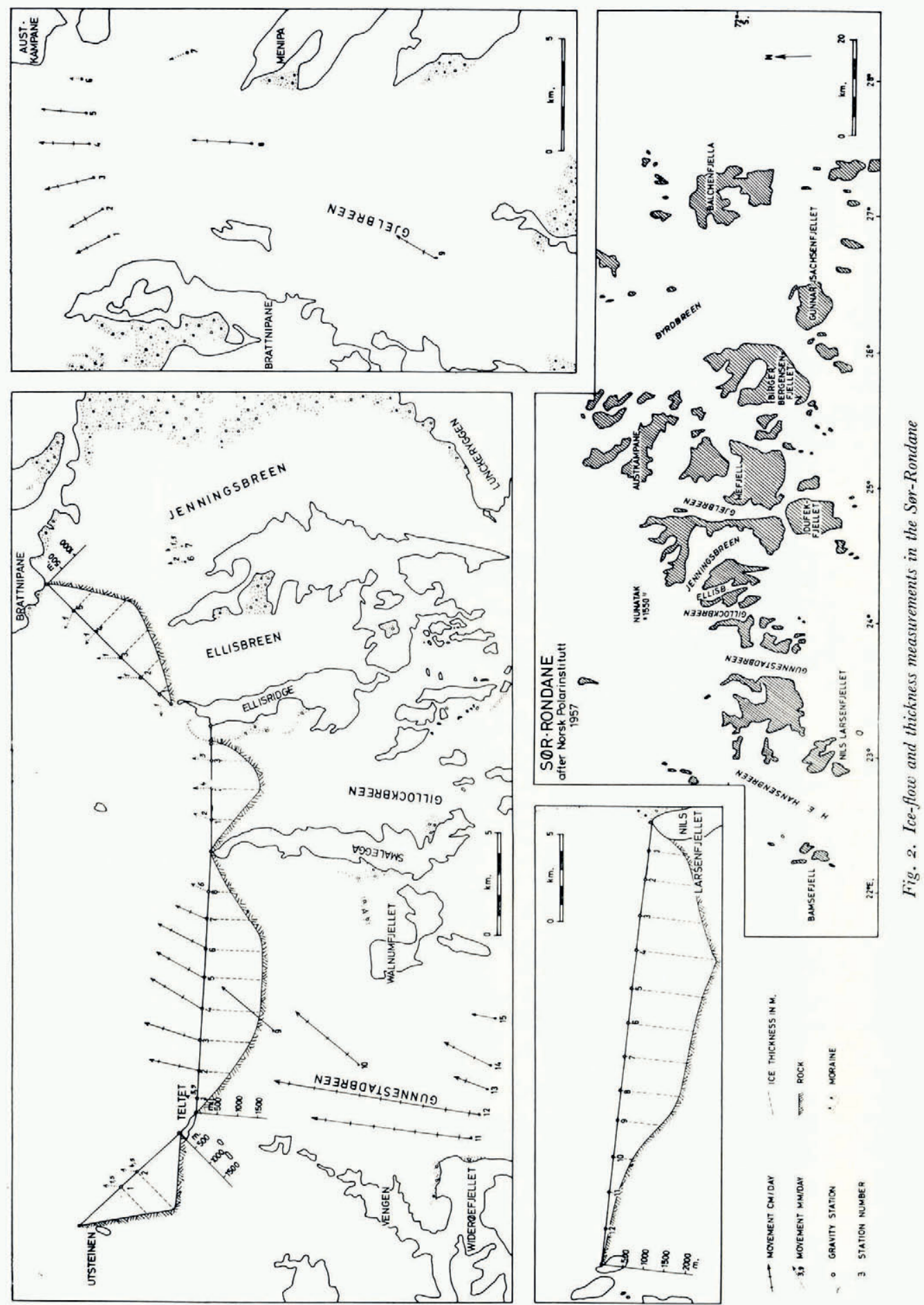




\section{Observations}

Ice-thickness and movement measurements were carried out on the following glaciers: Gunnestadbreen ( 2 profiles), Gillockbreen, the glacier between Teltet and Utsteinen, and Jenningsbreen. In addition, movement was observed on Gjelbreen and ice thickness was measured on H.E. Hansenbreen, on several smaller glaciers, and on the inland ice slope. The latter measurements are not considered here (Fig. 2).

The profiles are approximately east-west (at right-angles to the main flow direction of the glaciers) with stations at $\mathrm{I}, 600 \mathrm{~m}$. intervals.

\section{Ice-flow measurements}

During 1959 and I96o a triangulation scheme was observed in the Sør-Rondane. The geodetic and survey work consisted of about 40 triangulation stations covering an area about 200 by $50 \mathrm{~km}$. (Blaiklock, unpublished). The geographical coordinates of Teltet, the primary triangulation station, were determined by astral observations. After adjustment of the scheme, the geographical positions of the individual stations were calculated and they were then transposed into grid coordinates.

Heights in the Sør-Rondane were all related through the triangulation observations to Teltet "I920". Teltet itself was tied to "Base Roi Baudouin" and sea-level by aneroid barometer traverse. The mean of four main traverses observed during I959-6 I was used. On each traverse three aneroids were read. The standard error of the mean is $5 \mathrm{~m}$. The positions and heights of the markers of the glaciological-gravimetric traverses were fixed by theodolite resection from the main triangulation scheme. Observations at the glacier stakes were repeated as frequently as possible.

At the resected glaciological stations, two sets of horizontal angles and one set of vertical angles were observed with a Wild $\mathrm{T}_{2}$ theodolite. Usually five to seven points that had been given coordinates previously were chosen. Where possible, they were triangulation stations themselves or well-fixed peaks. At stations in the middle of glaciers it was easier to choose wellplaced peaks around the horizon, but some of the gravity stations on rock were at the bottom of ridges, so that visibility was restricted to one-half of the horizon.

The positions of the stations were calculated by a semi-graphical method. The coordinates of the triangulation sections used were the preliminary ones calculated during the winter at "Base Roi Baudouin" and not those finally computed at the Institut Géographique Militaire in Brussels. However, the final coordinates differ from the preliminary ones by only very small amounts and it was considered unnecessary to recalculate the resected positions, inasmuch as only differences between successive positions of the glacier stakes are considered.

For the glaciological stakes, the actual movement is of more interest than the true position. At stake II on Gunnestadbreen four resections were observed over a period of 32 months (Fig. 3). The direction and amplitude of the movement did not vary appreciably for the three intermediate periods. The coordinates of any resection are considered to be accurate to less than $0.5 \mathrm{~m}$. relative to one another.

The results of ice-flow measurements for the $1959-6$ I period are given in Table I, and those for the $1960-65$ period are given in Table II. A comparison between velocity figures for the same marker stakes during these two periods shows remarkably good agreement.

\section{Gravity measurements}

The gravimetric work of the 1959 and 1960 Expéditions Antarctiques Belges included relative measurements of gravity and an airborne survey, which was intended as a contribution to regional gravity mapping (Van Autenboer, I964[b]). For glaciological purposes only differences in gravity were measured. The stations were the same as those used for the velocity measurements, with an additional station on rock at each end of the profile. The profiles were 


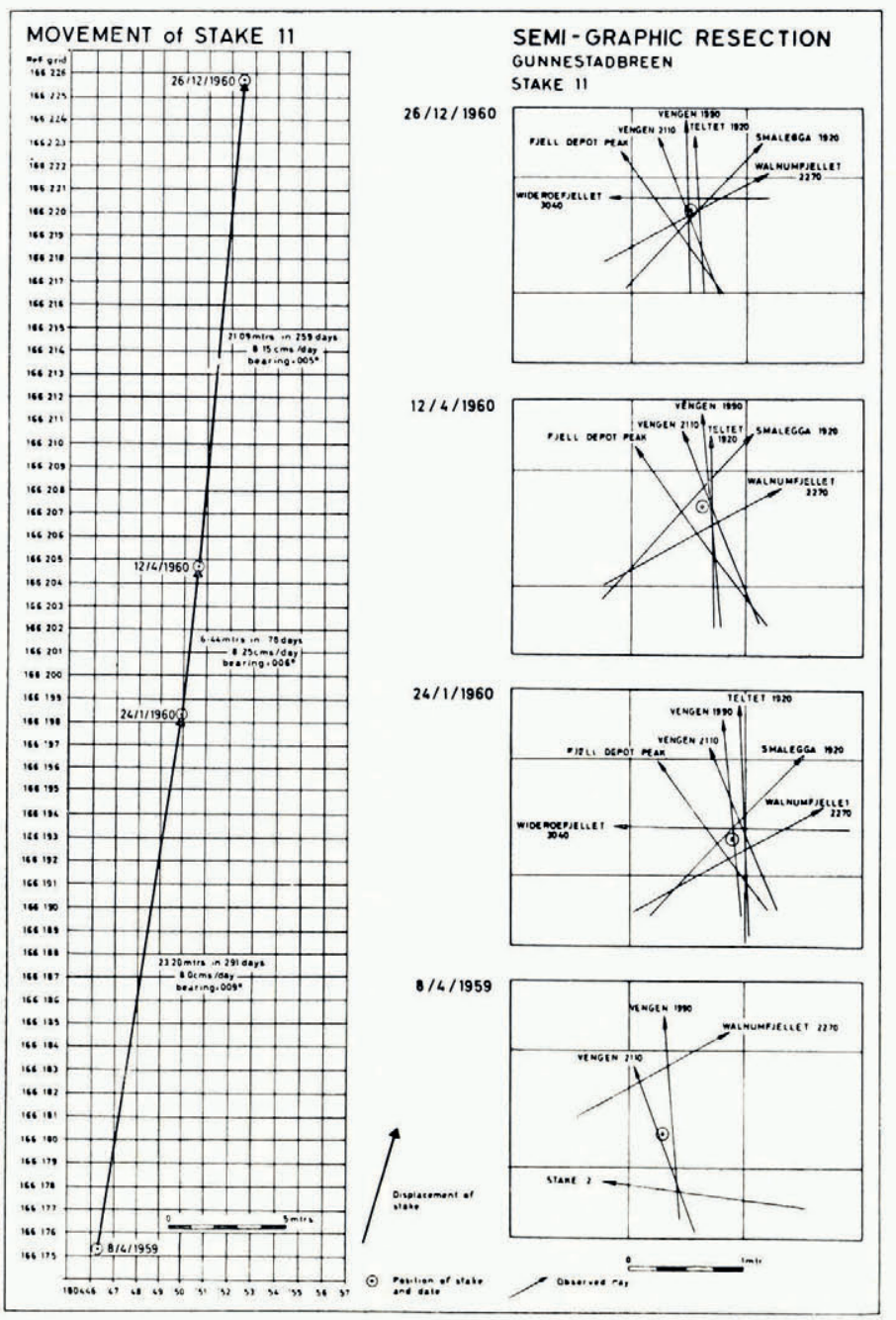

Fig. 3. Diagrams illustrating the semi-graphical resection of stake II on Gunnestadbreen at four observation dates, and the calculation of its velocity and direction

measured twice in each direction and the mean of the measured differences was taken. Correction for drift was only occasionally possible. A Worden geodetic-type gravimeter (No. 453) was used, and it had been checked on the Belgian and international (Oslo-Bodø) calibration bases. The calibration curve supplied by the manufacturers was found to be satisfactory and it was used for the computations. Transport for the glaciological gravity measurements was mainly by dog sledge and the gravimeter was suspended in a framework rigged on the back of the sledge. Using a thoroughly trained dog team pulling a well-loaded sledge and with some care to avoid steep blue-ice areas, this method of transport proved to be satisfactory. A preliminary reconnaissance to select a smooth part of the glacier and to find easy access to rock on both sides of the glacier was often necessary. The elevation and latitude determinations for the stations have been described above. 
Table I. Ice-flow Measurements in the Sør-Rondane, I959-6I*

\begin{tabular}{|c|c|c|c|c|c|}
\hline $\begin{array}{l}\text { Stake } \\
\text { number }\end{array}$ & Period of observation & $\begin{array}{l}\text { Number } \\
\text { of days }\end{array}$ & $\begin{array}{c}\text { Total } \\
\text { movement } \\
\mathrm{m} .\end{array}$ & $\begin{array}{l}\text { Movement } \\
\mathrm{cm} . / \text { day }\end{array}$ & $\begin{array}{c}\text { True } \\
\text { azimuth }\end{array}$ \\
\hline \multicolumn{6}{|c|}{ Glacier between Teltet and Utsteinen } \\
\hline I & 4 December $1959-22$ December 1960 & 384 & $1 \cdot 30$ & $0 \cdot 35$ & $000^{\circ}$ \\
\hline 2 & 4 December 1959-22 December I96o & $3^{84}$ & $1 \cdot 70$ & $0 \cdot 45$ & $000^{\circ}$ \\
\hline \multicolumn{6}{|c|}{ Gunnestadbreen } \\
\hline I & 20 January-2 I December i96o & 335 & $\mathrm{I} \cdot 3^{2}$ & $0 \cdot 39$ & $009^{\circ}$ \\
\hline 2 & 20 January-2 I December i 960 & 335 & $8 \cdot 27$ & $2 \cdot 50$ & $015^{\circ}$ \\
\hline 3 & 20 January-2 I December I96o & 335 & $10 \cdot 18$ & $3 \cdot 00$ & $020^{\circ}$ \\
\hline \multirow[t]{4}{*}{4} & 25 January -4 April 1960 & 70 & $2 \cdot 36$ & $3 \cdot 40$ & $036^{\circ}$ \\
\hline & 4 April-20 December 1960 & 260 & $7 \cdot 11$ & $2 \cdot 70$ & $028^{\circ}$ \\
\hline & 25 January-20 December 1960 & $33^{\circ}$ & $9 \cdot 45$ & $2 \cdot 90$ & $030^{\circ}$ \\
\hline & Total period & 660 & $18 \cdot 9^{2}$ & $2 \cdot 86$ & $029^{\circ}$ \\
\hline 5 & 7 February-20 December 1960 & 317 & $8 \cdot 24$ & $2 \cdot 60$ & $029^{\circ}$ \\
\hline 6 & 7 February-20 December 1960 & 317 & $8 \cdot 4^{1}$ & $2 \cdot 65$ & $028^{\circ}$ \\
\hline 7 & 7 February-20 December 1960 & 317 & $5 \cdot 4^{I}$ & $\mathrm{I} \cdot 7^{\circ}$ & $025^{\circ}$ \\
\hline 8 & 5 February-20 December i 960 & 319 & I $\cdot 97$ & 0.60 & $024^{\circ}$ \\
\hline 9 & I3 April-27 December I96o & $25^{8}$ & $9 \cdot 45$ & $3 \cdot 70$ & $040^{\circ}$ \\
\hline Io & 13 April-27 December 1960 & $25^{8}$ & I0. 44 & $4 \cdot 00$ & $040^{\circ}$ \\
\hline \multirow[t]{4}{*}{ I I } & 8 April r959-24 January 1960 & 291 & $23 \cdot 28$ & $8 \cdot 00$ & $009^{\circ}$ \\
\hline & 24 January-I I April ig6o & 78 & $6 \cdot 44$ & $8 \cdot 25$ & $006^{\circ}$ \\
\hline & I I April-26 December i96o & 259 & $21 \cdot 09$ & $8 \cdot 15$ & $005^{\circ}$ \\
\hline & Total period & 628 & $50 \cdot 8 \mathrm{I}$ & $8 \cdot 09$ & $006^{\circ}$ \\
\hline \multirow[t]{4}{*}{12} & 8 April I959-24 January 1960 & $29^{I}$ & $30 \cdot 53$ & $10 \cdot 5^{0}$ & $009^{\circ}$ \\
\hline & 24 January-12 April I96o & 79 & $8 \cdot 34$ & 10.55 & $010^{\circ}$ \\
\hline & I2 April-26 December 196o & $25^{8}$ & $26 \cdot 97$ & $10 \cdot 45$ & $008^{\circ}$ \\
\hline & Total period & 628 & $65 \cdot 84$ & $10 \cdot 4^{8}$ & $009^{\circ}$ \\
\hline \multirow[t]{4}{*}{13} & 8 April I959-24 January I96o & $29^{1}$ & $4 \cdot 4^{\circ}$ & $1 \cdot 50$ & $017^{\circ}$ \\
\hline & 24 January-12 April I96o & 79 & I $\cdot 24$ & $1 \cdot 60$ & $014^{\circ}$ \\
\hline & 12 April-26 December 196o & 258 & $3 \cdot 9^{I}$ & $1 \cdot 50$ & $032^{\circ}$ \\
\hline & Total period & 628 & $9 \cdot 55$ & $\mathrm{I} \cdot 5^{2}$ & $022^{\circ}$ \\
\hline \multirow[t]{4}{*}{14} & 8 April I959-24 January I96o & 291 & $7 \cdot 69$ & $2 \cdot 65$ & $028^{\circ}$ \\
\hline & 24 January-1 2 April 196o & 79 & $2 \cdot 06$ & $2 \cdot 60$ & $023^{\circ}$ \\
\hline & 12 April-26 December I96o & 258 & $6 \cdot 3 \mathrm{I}$ & $2 \cdot 45$ & $025^{\circ}$ \\
\hline & Total period & 628 & I6. o6 & $2 \cdot 5^{6}$ & $025^{\circ}$ \\
\hline \multirow[t]{3}{*}{ I 5} & 8 April I959-24 January I96o & 291 & $3 \cdot 26$ & $1 \cdot 10$ & ого \\
\hline & 24 January-I 2 April I96o & 79 & $0 \cdot 7 \mathrm{I}$ & $0 \cdot 90$ & $008^{\circ}$ \\
\hline & Total period & $37^{\circ}$ & $3 \cdot 97$ & $\mathrm{I} \cdot 07$ & $009^{\circ}$ \\
\hline \multicolumn{6}{|c|}{ Gillockbreen } \\
\hline $\begin{array}{l}\text { I } \\
2\end{array}$ & 13.January-16 December I96o & $33^{8}$ & $0 \cdot 54$ & $0 \cdot 20$ & $022^{\circ}$ \\
\hline $\begin{array}{l}2 \\
3\end{array}$ & I 3 January-16 December 1960 & $33^{8}$ & $1 \cdot 20$ & $0 \cdot 40$ & $005^{\circ}$ \\
\hline 3 & 6 March-16 December i 960 & 285 & $0 \cdot 90$ & $0 \cdot 30$ & $006^{\circ}$ \\
\hline \multicolumn{6}{|c|}{ Jenningsbreen } \\
\hline I & 3 March-1 7 December i96o & 289 & $0 \cdot 30$ & 0.10 & $270^{\circ}$ \\
\hline 2 & 3 March-1 7 December 1960 & 289 & $0 \cdot 30$ & $0 \cdot 10$ & $000^{\circ}$ \\
\hline 3 & 24 Fcbruary-17 December 1960 & 297 & $0 \cdot 4^{0}$ & 0.10 & $000^{\circ}$ \\
\hline 4 & I 7 March-1 7 December i 960 & 275 & $0 \cdot 42$ & 0.15 & $315^{\circ}$ \\
\hline 5 & I7 March-1 December I96o & 259 & $0 \cdot 3^{6}$ & $0 \cdot 10$ & $300^{\circ}$ \\
\hline 6 & 20 April I960-1 January I96I & 256 & $0 \cdot 4^{0}$ & $0 \cdot 20$ & $\mathrm{OOO}^{\circ}$ \\
\hline 7 & 20 April I96o-I January 196I & 256 & $0 \cdot 35$ & $0 \cdot 15$ & $350^{\circ}$ \\
\hline \multicolumn{6}{|c|}{ Q Fehruary-1 December u660 } \\
\hline I & 28 February-I I December 196o & 287 & $5 \cdot 28$ & $I \cdot 80$ & $335^{\circ}$ \\
\hline 2 & 28 February-I I December I96o & 287 & $5 \cdot 83$ & $2 \cdot 00$ & $329^{\circ}$ \\
\hline 3 & 27 February-1 I December 1960 & 288 & $7 \cdot 24$ & $2 \cdot 5^{\circ}$ & $349^{\circ}$ \\
\hline 4 & 28 February-1 i December 1960 & 287 & $7 \cdot 21$ & $2 \cdot 5^{0}$ & 002 \\
\hline 5 & 27 February-13 December I96o & 290 & $6 \cdot 00$ & $2 \cdot 10$ & $\mathrm{OO} 2^{\circ}$ \\
\hline 6 & 26 February-13 December i 960 & $29^{1}$ & $2 \cdot 30$ & $0 \cdot 80$ & $000^{\circ}$ \\
\hline 7 & 2 March-6 December 1960 & 279 & 0.67 & $0 \cdot 20$ & $333^{\circ}$ \\
\hline 8 & 29 February-9 December i96o & 286 & $7 \cdot 9^{1}$ & $2 \cdot 80$ & $003^{\circ}$ \\
\hline 9 & I March-8 December 1960 & 283 & $7 \cdot 30$ & $2 \cdot 60$ & $036^{\circ}$ \\
\hline \multicolumn{6}{|c|}{$\begin{array}{lr}\text { Piedmont zone } \dagger \\
6\end{array}$} \\
\hline 6 & 21 April I96o-r6 January I96I & 270 & $5 \cdot 10$ & $I \cdot 90$ & $028^{\circ}$ \\
\hline
\end{tabular}

* For position and graphical presentation of results see Figure 2.

† Stake 6 is situated ro km. north of nunatak "I 550 " on the Norwegian map. 
Table II. Ice-flow Measurements in the Sør-Rondane, i96o-65*

\begin{tabular}{|c|c|c|c|c|c|}
\hline $\begin{array}{l}\text { Stake } \\
\text { number }\end{array}$ & Period of observation & $\begin{array}{l}\text { Number } \\
\text { of days }\end{array}$ & $\begin{array}{c}\text { Total } \\
\text { movement }\end{array}$ & Movement & $\begin{array}{c}\text { True } \\
\text { azimuth }\end{array}$ \\
\hline \multicolumn{3}{|c|}{ Glacier between Teltet and Utsteinen } & $\mathrm{m}$. & $\mathrm{cm} . /$ day & \\
\hline 1 & 22 December $1960-28$ January 1965 & I 498 & $3 \cdot 5^{8}$ & 0.24 & $030^{\circ}$ \\
\hline 2 & 22 December I $960-28$ January 1965 & I 498 & $3 \cdot 9^{2}$ & $0 \cdot 26$ & $03^{\circ}$ \\
\hline \multicolumn{6}{|c|}{ Gunnestadbreen } \\
\hline I & 21 December $1960-28$ January 1965 & I 499 & $5 \cdot 57$ & $0 \cdot 37$ & $006^{\circ}$ \\
\hline 2 & 2 I December i96o-28 January i 965 & I 499 & $36 \cdot 68$ & $2 \cdot 45$ & $015^{\circ}$ \\
\hline 3 & 2 I December ig6o-27 January 1965 & 1498 & $49 \cdot 08$ & $3 \cdot 28$ & $024^{\circ}$ \\
\hline 4 & 20 December I96o-27 January 1965 & I 499 & $4 \mathrm{I} \cdot 59$ & $2 \cdot 77$ & $029^{\circ}$ \\
\hline 5 & 20 December I96o-26 January 1965 & I $49^{8}$ & $3^{8} \cdot 4^{8}$ & $2 \cdot 57$ & $028^{\circ}$ \\
\hline 6 & 20 December I96o-26 January 1965 & I 498 & $3^{8} \cdot 20$ & $2 \cdot 55$ & $026^{\circ}$ \\
\hline 7 & 20 December I96o-25 January i 965 & 1497 & $26 \cdot 22$ & $\mathrm{I} \cdot 75$ & $023^{\circ}$ \\
\hline 8 & 20 December i $960-25$ January I 965 & I 497 & $9 \cdot 45$ & 0.63 & $023^{\circ}$ \\
\hline \multicolumn{6}{|c|}{ Gillockbreen } \\
\hline I & I6 December I96o-25 January I 965 & 1501 & I $\cdot 40$ & $0 \cdot 09$ & $004^{\circ}$ \\
\hline 2 & I6 December I96o-25 January I 965 & 1501 & $3 \cdot 67$ & $0 \cdot 24$ & OI $1^{\circ}$ \\
\hline \multicolumn{5}{|c|}{ Jenningsbreen } & \\
\hline 2 & 17 December 1960-25 January 1965 & 1500 & $\mathrm{I} \cdot 7 \mathrm{I}$ & O. II & $339^{\circ}$ \\
\hline 4 & I 7 December 1960-24 January I 965 & 1499 & $2 \cdot 78$ & $0 \cdot 19$ & $308^{\circ}$ \\
\hline 6 & I January I96I-24 January 1965 & 1484 & $\mathrm{I} \cdot 36$ & 0.09 & $343^{\circ}$ \\
\hline$\stackrel{7}{\text { Gjelbrees }}$ & I January I 96 I-25 January I 965 & 1485 & $1 \cdot 30$ & 0.09 & $344^{\circ}$ \\
\hline 5 & ${ }_{13}$ December $1960-23$ January 1965 & ${ }^{1} 502$ & $32 \cdot 4^{2}$ & $2 \cdot 16$ & $35^{8^{\circ}}$ \\
\hline 7 & 6 December $1960-23$ January 1965 & 1509 & $2 \cdot 22$ & O. I 5 & $324^{\circ}$ \\
\hline
\end{tabular}

Martin ([1949]) was the first person to use gravity measurements for the determination of ice thickness. In his method, as it has been applied here, the observed gravity value at a glaciological station is reduced to the elevation and latitude of a reference station on rock. The density of ice $\left(0.9^{2} \mathrm{~g} . / \mathrm{cm} .{ }^{3}\right)$ is used in the combined (free-air and Bouguer) elevation correction, implying the existence beneath the glaciological station of an infinite slab of ice, the thickness of which is equal to the difference in elevation between the two stations. This assumption would be correct when the value at the reference station and the reduced value of the glaciological station are equal. A difference between these two values is considered as an anomaly and requires further interpretation.

Since no information on other causes affecting the gravity values is available, the observed anomaly is explained by assuming that the thickness of the ice, and consequently the height of the rock basement, differs from the assumption by an amount $h_{2}$.

It is therefore equal to the difference between the Bouguer corrections for density, $d_{\mathrm{I}}$ (ice) and $d_{2}$ (rock), applied to an infinite slab of height, $h_{2}$, which equals the difference in elevation between the rock basement and the reference level, i.e. $h_{2}=$ Anomaly $/ L\left(d_{2}-d_{\mathrm{I}}\right)$. This difference is negative when the subglacial topography lies below the reference level and positive when it lies above it. However, Martin allowed no correction for the regional variation of gravity which is contained in the observed gravity (Littlewood, I952). On longer traverses this might introduce a large error and especially in Antarctica where a large anomaly gradient can be expected, as there is a trend towards isostatic equilibrium of the crust under the load of the Antarctic Ice Sheet.

Bull and Hardy ( $195^{6}$ ), in their work on Austerdalsbreen in Norway, interpolated a curve of regional anomalies based upon the anomalies at the rock stations at each end of the profile. The shape of the curve is based upon the anomaly curves measured in the lower ice-free parts of the glacier valley.

For the present interpretation there is no information regarding the curve of regional anomalies and therefore the gradient has been assumed to be linear between the rock stations at each end of the traverses. The difference between the two values at the rock stations, after 
reduction to the same height and latitude, has been distributed over the profile. Further calculations were carried out using Martin's method and in Figures $4^{-8}$ the calculated crossprofiles are represented by a dotted line.

In the calculations using Martin's method the presence of an infinite slab of ice beneath the stations is implied in the Bouguer correction. This assumption can be applied to gravity stations on a large continental ice sheet if the subglacial bedrock relief is simple. However, it is bound to introduce a serious error when a valley glacier with a U-shaped cross-profile and well-confined boundaries is considered. Since this was true in the case of the Sør-Rondane glaciers, a check was necessary. This was kindly done by Ir. L. Jones, Géographe à l'Institut Géographique Militaire in Brussels, who suggested the method and carried out the computations. In this procedure the Bouguer anomalies were first computed* for a two-dimensional model of a glacial valley having the cross-profile estimated by Martin's method. Two of the dimensions of this model, representing the cross-section of the glacier, are situated within the vertical plane of the gravimetric profile. The third one, perpendicular to this plane, is assumed to be infinite and corresponds to the long axis of the glacier. Comparisons of the anomalies calculated by this method and the observed anomalies show a serious discrepancy (or remanent anomaly) (Figs. 4-8). This discrepancy is greatest in the central part of the glacier where the gravity effect of the basement rising towards the boundaries of the glacier has to be accounted for. The thicknesses calculated by Martin's method apparently do not correspond with the true ones.

In order to achieve a better approximation to the subglacial profiles, further models were successively chosen, their effects calculated using Hubbert's method and compared with the curve of observed anomalies. When the calculated curve of anomalies coincides with the observed one, the model apparently represents the cross-section of the glacier, excluding the effects of possible geological accidents and of changes in densities (e.g. moraines contained within the ice). For practical purposes the results are considered satisfactory when the two curves are within a few milligals of each other. The adopted ice thicknesses at the glaciological stations are given in Table III and are represented in Figures 2 and $4^{-8 .}$

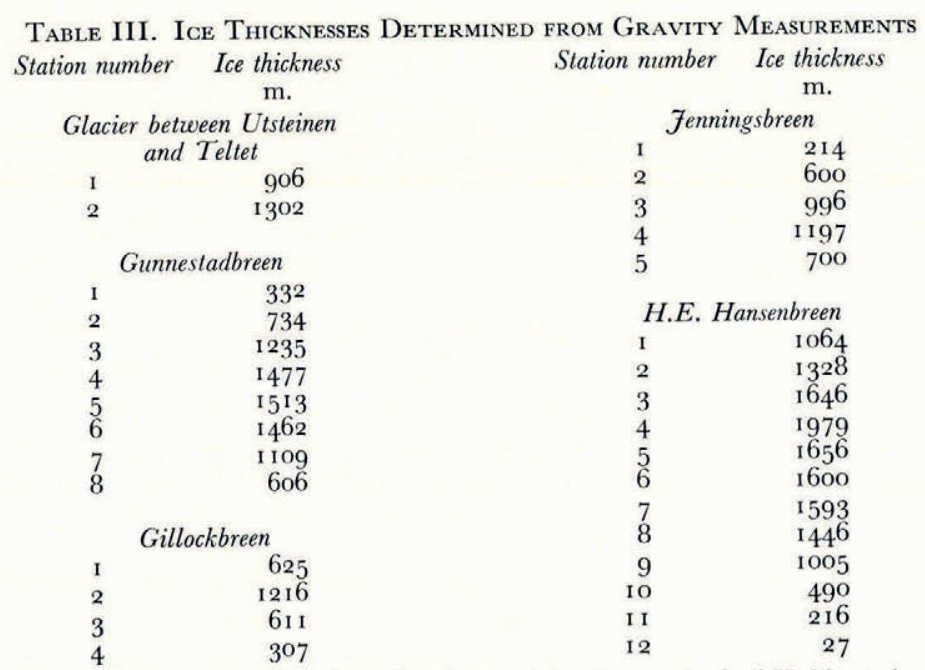

* For the calculation of the anomalies given by the models, the method of Hubbert (1948) was used. This method has been used by Thiel and others (1957) on a glacier in Alaska. The programming of this method has been carried out by Talwani and others (1959) for an IBM 650 computer and by Chevalier (I963) for the CAB 500 computer used for this study. To calculate the effect of the model, the following data are required: the abscissa of each station, coordinates (abscissa and ordinate, or ice thickness) of the different summits of the model, related to a chosen station of origin, and the density contrast. For the preliminary calculations the "standard" densities of $2.67 \mathrm{~g} . / \mathrm{cm} .^{3}$ (for rock) and $0.9^{2} \mathrm{~g} . / \mathrm{cm} .^{3}$ (for ice) were used. 


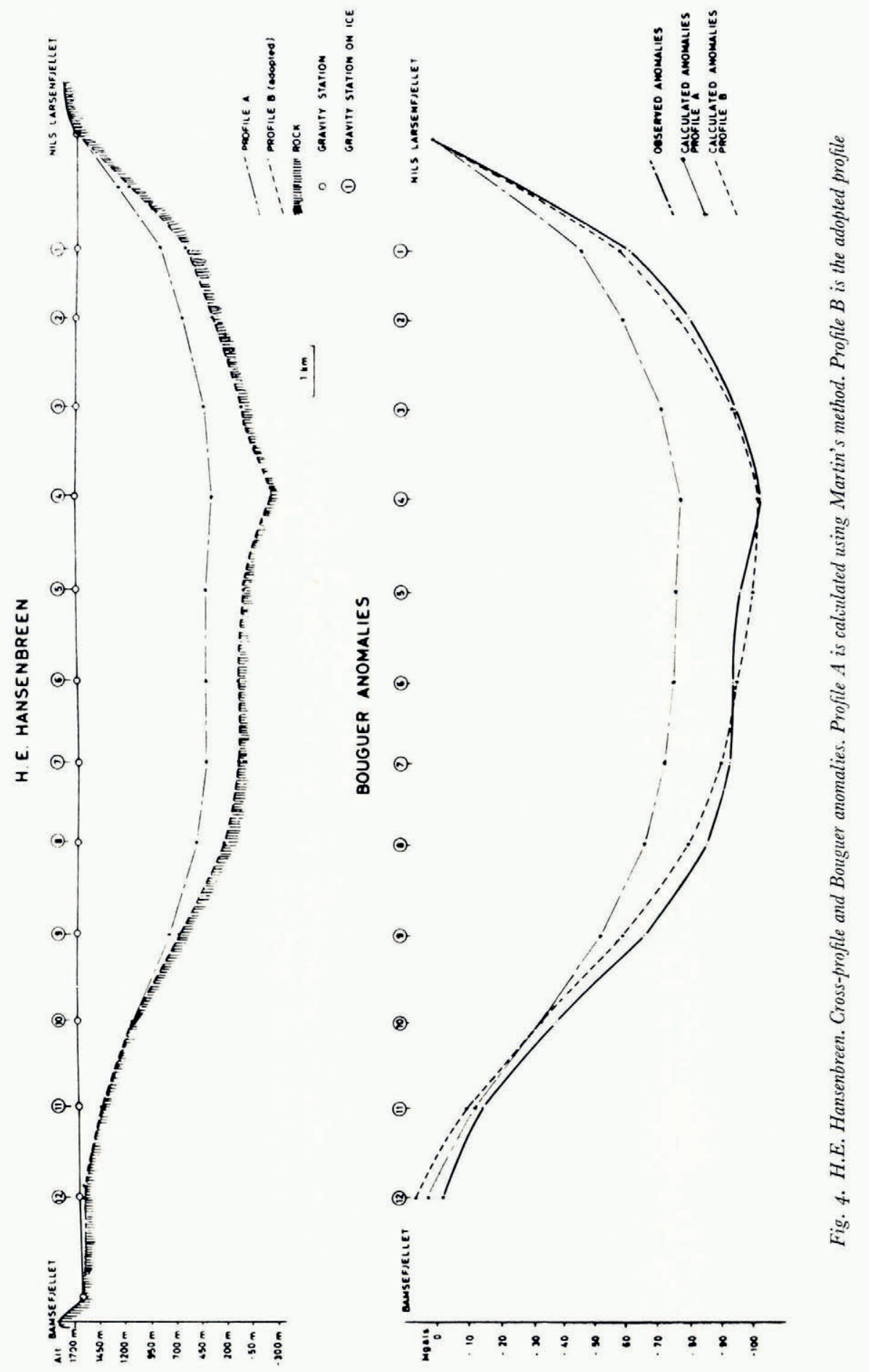




\section{GLACIER BETWEEN TELTET AND UTSTEINEN}

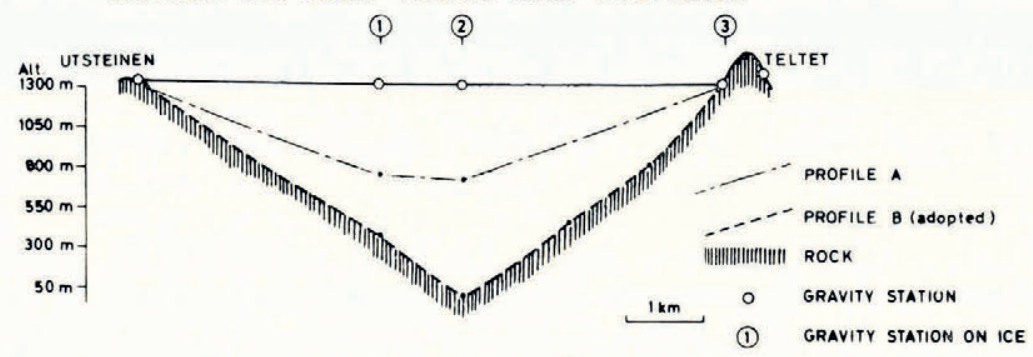

BOUGUER ANOMALIES

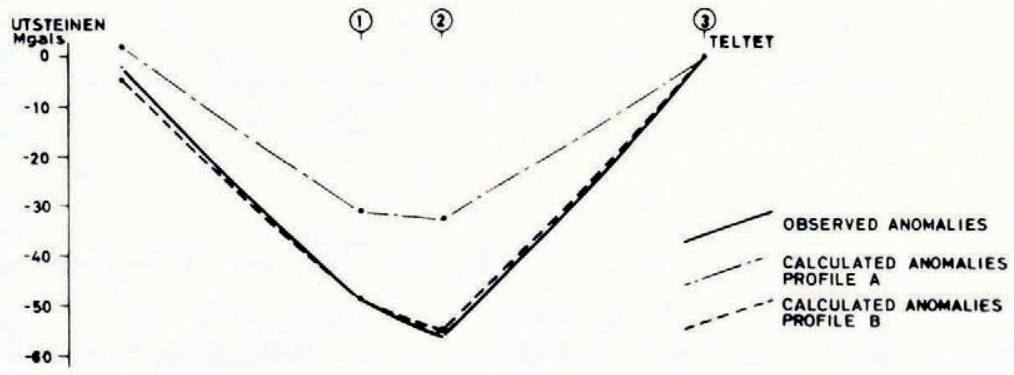

Fig. 5. Glacier between. Teltet and Utsteinen. Cross-profile and Bouguer anomalies. Profile A is calculated using Martin's method. Profile $B$ is the adopted profile
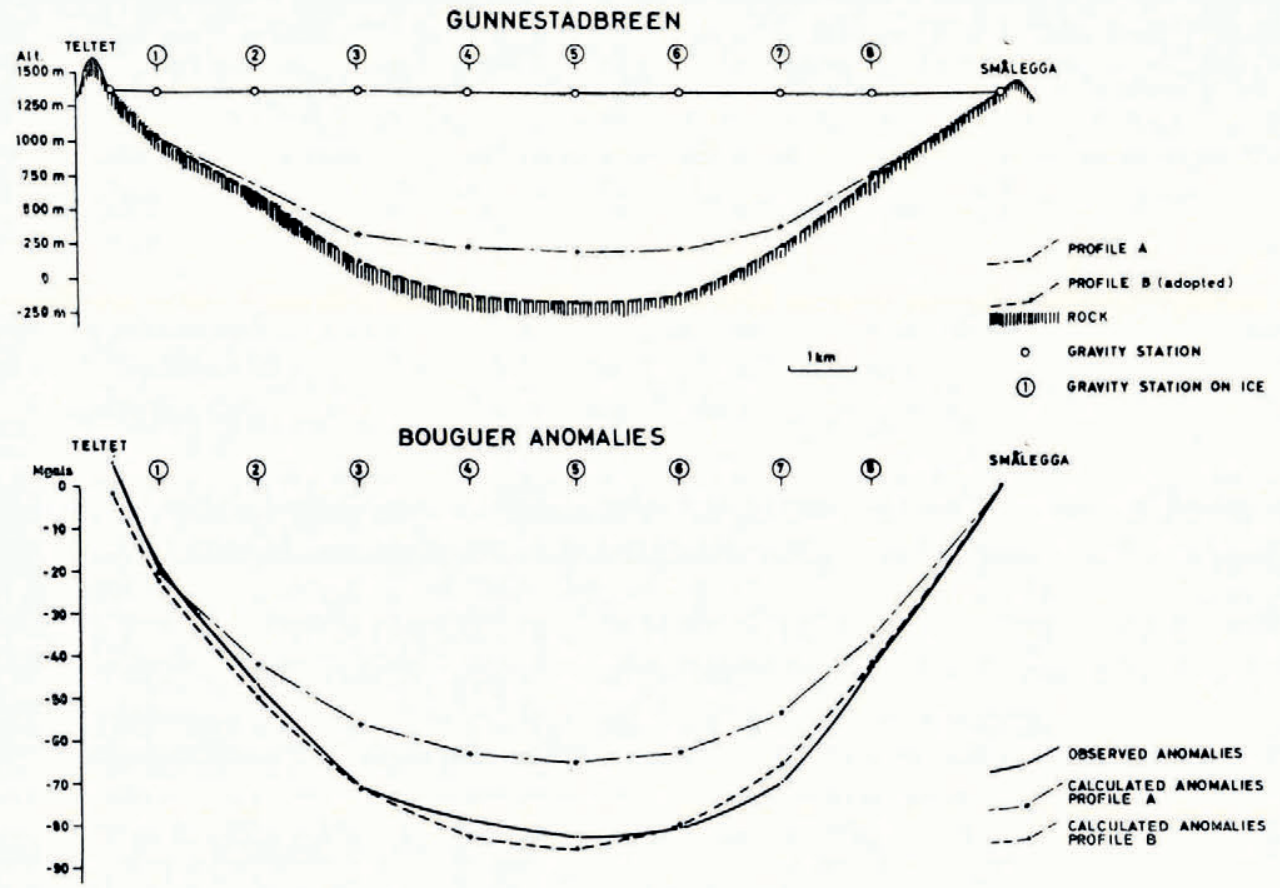

Fig. 6. Gunnestadbreen. Cross-profile and Bouguer anomalies. Profile A is calculated using Martin's method. Profile B is the adopted profile 


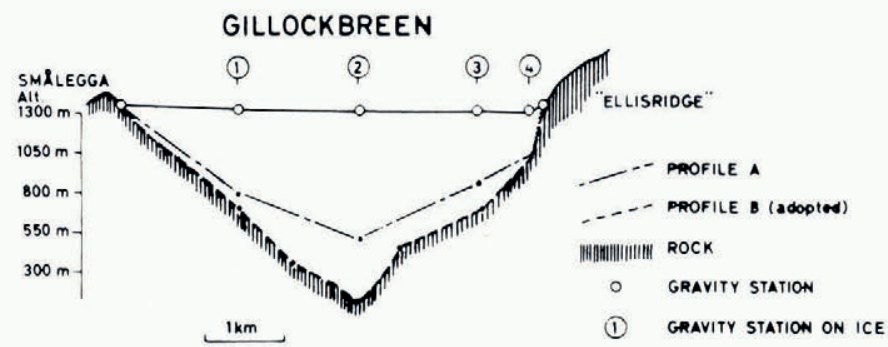

BOUGUER ANOMALIES

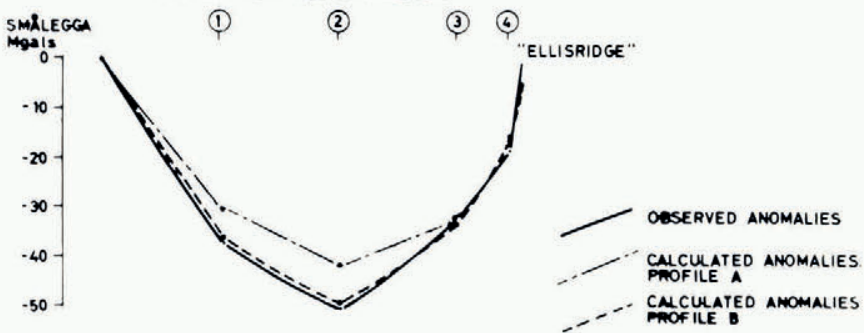

Fig. 7. Gillockbreen. Cross-profile and Bouguer anomalies. Profile A is calculated using Martin's method. Profile B is the adopted profile
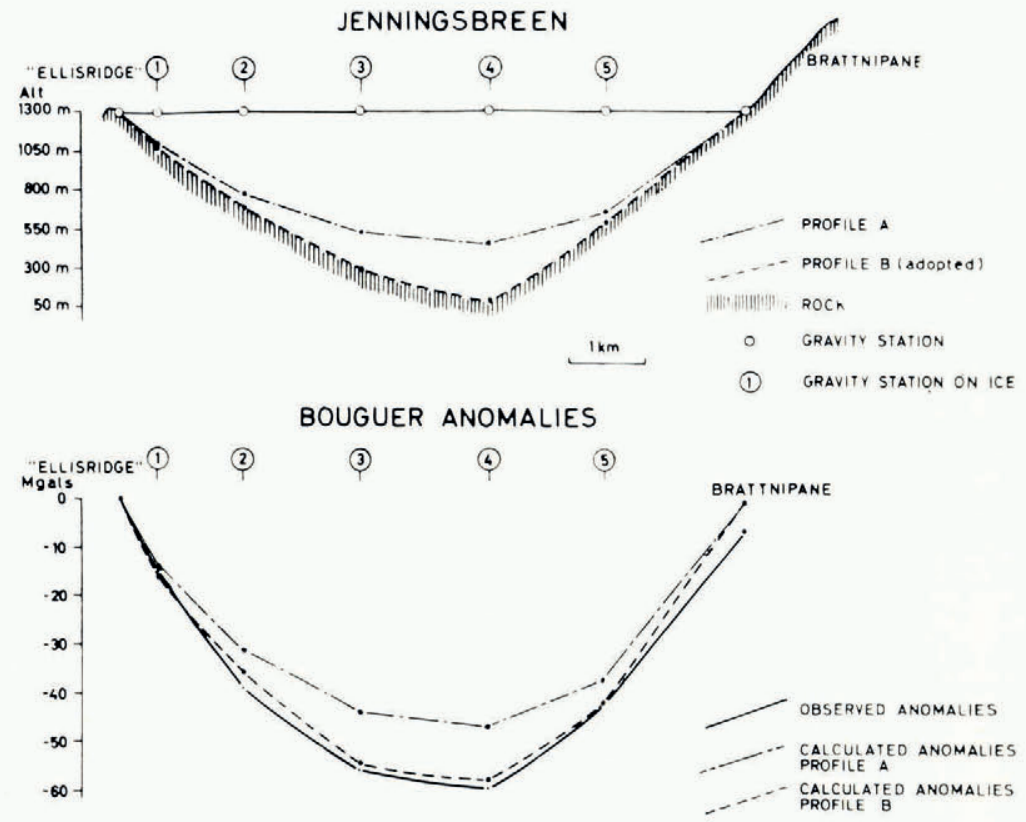

Fig. 8. Jenningsbreen. Cross-profile and Bouguer anomalies. Profile A is calculated using Martin's method. Profile B is the adopted profile 


\section{Discussion}

Flow rates, directions of flow and ice thicknesses measured in the Sør-Rondane are represented in Figure 2. The annual discharge of four of the Sør-Rondane glaciers can now be roughly estimated. In this calculation the measured surface velocities were applied to corresponding vertical slabs of the cross-profile, drawn as a function of the determined ice thicknesses. As the vertical distribution of the rate of movement is not constant and diminishes downwards (Mathews, I959), these figures are maximum estimates.*

\section{Annual discharge}

Tons of ice $\times 10^{6}$

$\begin{array}{lr}\text { Glacier between Teltet and Utsteinen } & 2 \cdot 9 \\ \text { Gunnestadbreen } & 83 \cdot 8 \\ \text { Gillockbreen } & 3 \cdot \mathrm{I} \\ \text { Jenningsbreen } & \mathrm{I} \cdot 7\end{array}$

No velocity measurements were made on H.E. Hansenbreen. However, other observations (Van Autenboer, I964[a]) indicate that a greater rate of movement can be expected in this glacier. The cross-section of H.E. Hansenbreen is approximately $\mathrm{I} \cdot 85$ times the cross-section of Gunnestadbreen. By estimating its velocity as being at least twice the measured one for Gunnestadbreen, an estimate of $302 \times 10^{6}$ tons/yr. is reached. A comparison of the velocities of Gunnestadbreen and Gjelbreen indicates that the discharge of the latter should not exceed that of Gunnestadbreen.

A study of available air photographs $\uparrow$ and field observations indicates the main sources of nourishment of these glaciers (Van Autenboer, i964[a]).

It is likely that the discharge of H.E. Hansenbreen exceeds the total discharge over a large part of the western part of the range. The Sør-Rondane generally acts as a barrier and dams the flow of ice from the polar plateau. The drainage in the areas to the east and the west of the range, which are free from obstruction, is far more important than the discharge through it. H.E. Hansenbreen is situated at the western limit of the range and its discharge clearly indicates the importance of this deflected flow.

Gunnestadbreen is clearly the most important of the glaciers within the range for which an estimate is available. This glacier is actively fed from the polar plateau. From the r959 Norwegian air photographs, it appears that to the south there is a trough which funnels the plateau ice supply into the narrow confines of the lower reaches of the glacier. Local glaciers form an important contribution in addition to the plateau supply. These are small glaciers on the southern slopes of Widerøefjellet which discharge southwards and south-eastwards. Their local flow is deflected northwards when they join the main ice discharge from the polar plateau.

Quite a different situation exists east of Gunnestadbreen and south of Gillockbreen, Ellisbreen and Jenningsbreen. Here the Antarctic Ice Sheet approaches a local rise, as can be assumed from the nunataks projecting through it. The ice sheet glides evenly over this bedrock highland area as a smooth, featureless and crevasse-free plain, the ice of which is probably thinner than that supplying Gunnestadbreen. As it reaches the northern edge of the highland it cascades down into the three small glaciers.

* It has been shown (Van Autenboer, I $964[\mathrm{a}]$ ) that the present state of glacierization in the Sør-Rondane is a reduced one compared with former glacier coverage. The present glacier regime is believed to be in balance.

† 1946-47: trimetrogon photographs of United States Navy, Operation "Highjump" (leader R. Byrd); 1958: oblique air photographs of the Sør-Rondane by Norsk Polarinstitutt, Operation "Pingvin", 1958-59 (leader B. Lunke); 1960: trimetrogon photographs over part of the Sør-Rondane by Expédition Antarctique Belge i96o (leader G. Derom). 
The glacier between Utsteinen and Teltet has at present no direct supply from the polar plateau, although evidence of its former extension indicates that this was previously so. It is therefore a local glacier only because its ice supply has been cut off, and its estimated discharge is believed to reflect local nourishment.

There is clearly a direct relationship between the discharge of the Sør-Rondane drainage glaciers and their supply from the plateau.

\section{AcKnowledgements}

The authors wish to thank the members of the expeditions, especially G. Derom, J. Dubois, L. Goossens, J. Verheye and J. J. Derwael, who assisted with the field work. The advice and assistance of Ir. L. Jones, Géographe à l'Institut Géographique Militaire in Brussels, who introduced one of us (T.V.A.) to the use of a gravimeter, is gratefully acknowledged. He also carried out the second part of the calculation of the gravity measurements. Professor P. de Bethune (Université de Louvain) and Dr. J. Behrendt (Geophysical and Polar Research Center, University of Wisconsin) read the manuscript and contributed constructive criticism. Dr. R. J. Adie (British Antarctic Survey, Department of Geology, University of Birmingham) kindly revised the manuscript.

MS. received 27 March 1964 ; additions received 12 May 1965

\section{REFERENCES}

Autenboer, T. Van. 1962. Quelques aspects géographiques des Sor-Rondane, Terre de la Reine Maud, Antarctique. La Géographie (Gand), No. 3, p. 93-108.

Autenboer, T. Van. 1964 [a]. The geomorphology and glacial geology of the Sor-Rondane, Dronning Maud Land, Antarctica. Mededelingen van de Koninklijke Vlaamse Akademie voor Wetenschappen, Letteren en Schone Kunsten van België, Klasse der Wetenschappen, Jaarg. 26, Nr. 8.

Autenboer, T. Van. 1964[b]. Gravity measurements in the Sør-Rondane mountains, Dronning Maud Land. (In Adie, R. J., ed. Antarctic geology. Proceedings of the first international symposium on Antarctic geology. Cape Town, I6-2I September 1963. Amsterdam, North-Holland Publishing Co., p. 532-37.)

Blaiklock, K. V. Unpublished. Topographic and geodetic results of the Expéditions Antarctiques Belges I959 and r960. [Report submitted to the Centre National de Recherches Polaires de Belgique.]

Bull, C., and Hardy, J. R. 1956. The determination of the thickness of a glacier from measurements of the value of gravity. Journal of Glaciology, Vol. 2, No. 20, p. 755-63.

Chevalier, R. I 963 . Fonctionnement et utilisation de C.A.B. 5oo. Bruxelles, Institut Géographique Militaire.

Hubbert, M. K. I 948 . A line integral method of computing the gravimetric effects of two-dimensional masses. Geophysics, Vol. 13, No. 2, p. $215^{-25}$.

Littlewood, C. A. 1952. Gravity measurements on the Barnes Icecap, Baffin Island. Arctic, Vol. 5, No. 2, p. 1 I $8-24$.

Martin, J. [1949.] Gravimétrie. (In Rapport préliminaire de la compagne préparatoire au Groenland (I948). Publications des Expéditions Polaires Françaises. [No.] 5, p. 28-41.)

Mathews, W. H. r959. Vertical distribution of velocity in Salmon Glacier, British Columbia. Journal of Glaciology, Vol. 3, No. 26, p. 448-54.

Talwani, M., and others. I959. Rapid gravity computations for two-dimensional bodies with application to the Mendocino submarine fracture zone, by M. Talwani, J. L. Worzel and M. Landisman. Journal of Geophysical Research, Vol. 64, No. I, p. 49-6o.

Thiel, E., and others. 1957. The thickness of Lemon Creek Glacier, Alaska, as determined by gravity measurements, by E. Thiel, E. [R.] LaChapelle and J. [C.] Behrendt. Transactions. American Geophysical Union, Vol. 38, No. 5, p. $745^{-49}$. 